\title{
ANALISIS DISTRIBUSI SUHU PADA PELAT DUA DIMENSI DENGAN MENGGUNAKAN METODA BEDA HINGGA
}

\author{
Supardiyono \\ Jurusan Fisika FMIPA UNESA \\ Kampus Ketintang Surabaya e-mail: idayono@yahoo.com
}

\begin{abstract}
Abstrak
Telah dilakukan penelitian tentang komputasi distribusi suhu pada persamaan Laplace dua dimensi dengan metode beda hingga menggunakan MATLAB 7.0. Tujuan penelitian adalah menganalisis distribusi suhu pada tiap titik dalam dua dimensi pada persamaan Laplace. Metode penelitian yang digunakan yakni menyusun konsep persamaan Laplace, mengidentifikasi permasalahan, persamaan Laplace dua dimensi yang digunakan, penyelesaian numerik dengan metode beda hingga, uji kebenaran dan data awal, analisis, penerapan. Hasil penelitian menunjukkan bahwa visualisasi berupa grafik pada program MATLAB untuk menyelesaikan persamaan Laplace telah ada kecocokan dengan grafik pada teori tentang aliran suhu, sehingga antara hasil teori dan numerik berupa program tidak ada perbedaan yang signifikan. Bahkan hasilnya berdasarkan grafik diatas menunjukkan bahwa antara numerik dengan analitik saling berhimpit atau mendekati. Hal ini dapat dilihat dari selisih atau tingkat error nilai $\mathrm{T}$ antara numerik dengan analitik tidak terlalu jauh perbedaannya.
\end{abstract}

Kata kunci: metode beda hingga, distribusi suhu, persamaan Laplace 


\section{PENDAHULUAN}

Visualisasi komputer merupakan salah satu metode yang dapat digunakan untuk menggambarkan fenomenafenomena fisika secara jelas atau secara visual sehingga mudah untuk diamati dan di pahami. Demikian juga halnya dalam menjelaskan fenomena pada distribusi suhu dua dimensi yang merupakan aplikasi dari persamaan Laplace. Salah satu metode penyelesaian persamaan-persamaan fisika yang rumit secara analitik akan menjadi mudah bila menggunakan metode numerik. Beda hingga merupakan salah satu metode numerik yang dapat digunakan untuk memecahkan persamaan diferensial parsial.

Seiring perkembangan teknologi informasi, visualisasi dengan pemrograman komputer diharapkan dapat memainkan peranan penting dalam sains dan pendidikan. Diperlukan software yang dapat membantu mahasiswa untuk mengembangkan visualisasi komputer sebagai media pembelajaran, dalam hal ini pemrograman MATLAB 7.0 merupakan salah satu bahasa pemrograman untuk pembuatan program-program aplikasi fisika.

Persamaan Laplace adalah sebuah PDP (persamaan diferensial parsial) dengan bentuk persamaannya adalah [1]:

$$
\frac{\partial^{2} T}{\partial x^{2}}+\frac{\partial^{2} T}{\partial y^{2}}+\frac{\partial^{2} T}{\partial z^{2}}=0
$$

atau

$$
\nabla^{2} T=0
$$

untuk tiga dimensi, dan kita dapatkan pula persamaan Laplace dua dimensi

$$
\frac{\partial^{2} T}{\partial x^{2}}+\frac{\partial^{2} T}{\partial y^{2}}=0
$$

Dengan pemisahan variabel diperoleh penyelesaian umum dari persamaan Laplace dua dimensi diatas adalah [2]:

$$
\begin{aligned}
& T(x, y)=(A \cos k x+B \sin k x)\left(C e^{k y}+\right. \\
& \left.D e^{-k y}\right)
\end{aligned}
$$

Pemakaian persamaan Laplace dalam masalah fisika misalnya pada distribusi suhu dan distribusi potensial. Untuk menganalisis disribusi suhu pada pelat dua dimensi yang sesuai dengan persamaan Laplace secara numerik diperlukan beberapa teknik komputasi, salah satu diantaranya adalah metode beda hingga. Analisis numerik ini diperlukan untuk membuat media pembelajaran fisika yang berkaitan dengan distribusi suhu atau distribusi potensial secara visual. Tujuan penelitian adalah menganalisis distribusi suhu pada pelat dua dimensi yang sesuai dengan persamaan Laplace.

\section{KAJIAN TEORI}

\subsection{Metode Beda Hingga}

Metode beda hingga adalah suatu teknik analisa yang kuantitatip untuk solusi-solusi mendekati perolehan suatu permasalahan yang luas terkait keahlian teknik [3]. Metode ini adalah merancang untuk mempelajari penekanan distruktur - struktur tampilan dan kemudian menyesuaikan diri dengan sebuah bidang yang lebih luas dari mekanika, permasalahan keahlian teknik dipecahkan dengan menurunkan persamaan-persamaan diferensial berkenaan dengan masalah, untuk itu digunakan prinsip-prinsip persamaanpersamaan diferensial keseimbangan, hukum Newton yang kedua mengisyaratkan kekekalan massa, kekekalan tenaga, dan banyak lagi yang lain. Persamaan-persamaan differensial bagaimanapun, adalah sukar untuk dipecahkan walaupun hanya permasalahan yang sangat sederhana (sebagai contoh segi-empat, lingkar dll) bisa dipecahkan menggunakan persamaan-persamaan ini [3].

Sebagai konsekuensi metode beda hingga dari analisis adalah untuk membantu mengembangkan pemecahan di persamaan-persamaan differensial parsial ini. Metode beda hingga digunakan untuk memecahkan suatu masalah yang rumit dalam membagi masalah ke dalam permasalahan yang lebih kecil dan memecahkannya secara terpisah. Begitu metoda ini meneliti penyusunan model dari kecil dalam 
keadaan daerah terhubung pada daerah atau koordinat dari elemen-elemen, gagasan untuk metode beda hingga adalah suatu "daerah penyelesaian" yaitu, model dapat meneliti atau didekati dengan menggantikan daerah atau koordinat dengan jumlah elemen terbatas elemen yang terpisah, elemenelemen Ini kemudian bisa dijadikan tempat penyelesaian yang berbeda untuk menyusun permasalahan yang kompleks.

Aplikasi metode beda hingga terbagi dalam tiga kategori, tergantung pada sifat alami masalah yang akan dipecahkan. Ketiga kategori adalah permasalahan steady-state, permasalahan nilai Eigen dan permasalahan yang temporer.

Permasalahan steady-state digunakan pada permasalahan yang umum di analisis dengan metode beda hingga. Untuk suatu masalah elastis di keseimbangan dapat dipecahkan dan penyimpangannya dapat dihitung. Dihitung dari penggantian didapat tegangan. Untuk analisa yang berkenaan dengan panas, distribusi temperatur dan aliran bahan melalui suatu kondisikondisi pada luas batasnya [4].

Permasalahan nilai Eigen adalah suatu perluasan dari permasalahan keseimbangan. Mereka melibatkan kalkulasi karakteristik-karakteristik yang pokok dari sistem. Ini adalah permasalahan posisi mantap (steadystate) di mana penentuan frekuensi yang alami dan dari getaran padat mengalir [4].

Permasalahan yang temporer adalah terdiri atas permasalahan dua kategori pertama dengan sebuah waktu dimensi yang ditambahkan. Beban bisa merupakan suatu fungsi dari waktu, dan metoda finite element digunakan untuk mengkalkulasi menanggapi suatu persamaan. Perkembangannya menekan panas yang temporer membentuk bagian dari permasalahan yang temporer [4].

\subsection{Solusi Numerik}

Tujuan program MATLAB dengan metode beda hingga untuk mengkalkulasi suatu solusi yang kuantitatip. Solusi u untuk dua dimensional. Masalah Laplace (P) dengan kondisi batas yang sesuai, biarkan $\Omega \subset \Re^{2}$ dibatasi daerah Lipschitz dengan batas segi delapan $\Gamma$. Pada bagian tertutup $\Gamma_{D}$ dari batas dengan panjangnya yang positif, kita mengasumsikan kondisi Dirichlet, sedang mempunyai syarat batas Neumann dibagian yang sisanya $\Gamma_{N}:=\Gamma / \Gamma_{D}$. Dengan $f \in L^{2}(\Omega), u_{D} \in H^{1}(\Omega)$, dan $g \in L^{2}\left(\Gamma_{N}\right)$, mencari $u \in H^{1}(\Omega)$ dengan:

$-\Delta u=f \quad$ in $\Omega$,

$$
\begin{array}{cc}
u=u_{D} & \text { on } \Gamma_{D}, \\
\frac{\partial u}{\partial n}=g & \text { on } \Gamma_{N}
\end{array}
$$

Menurut Lax-Milgram Lemma [5], disana selalu ada suatu solusi yang lemah untuk persamaan (5) sampai (7) keteraturan dalam bagian (i.e, $u \in H_{l o c}^{2}(\Omega)$ ), dan pada kondisi keteraturan oleh karena hubungan dengan batas dan perubahan kondisi.

Kondisi-kondisi tidak setara Dirichlet (6) disatukan melalui $v=u-u_{D}$ sedemikian hingga $v=0 \mathrm{di}$ $\Gamma_{D}$, contoh:

$v \in H_{D}^{1}(\Omega):=\left\{\omega \in H^{1}(\Omega) \mid \omega=0\right.$ on $\left.\Gamma_{D}\right\}$

Kemudian, perumusan yang terbatas menghargai masalah $(\mathrm{P})$ : untuk mencari $v \in H_{D}^{1}(\Omega)$, seperti [5] :

$\int_{\Omega} \nabla v \cdot \nabla \omega d x=\int_{\Omega} f \omega d x+\int_{\Gamma N} g \omega d s-\int_{\Omega} \nabla u_{D} . \nabla \omega d x, \omega \in H_{D}^{1}(\Omega)$ 


\section{METODE PENELITIAN}

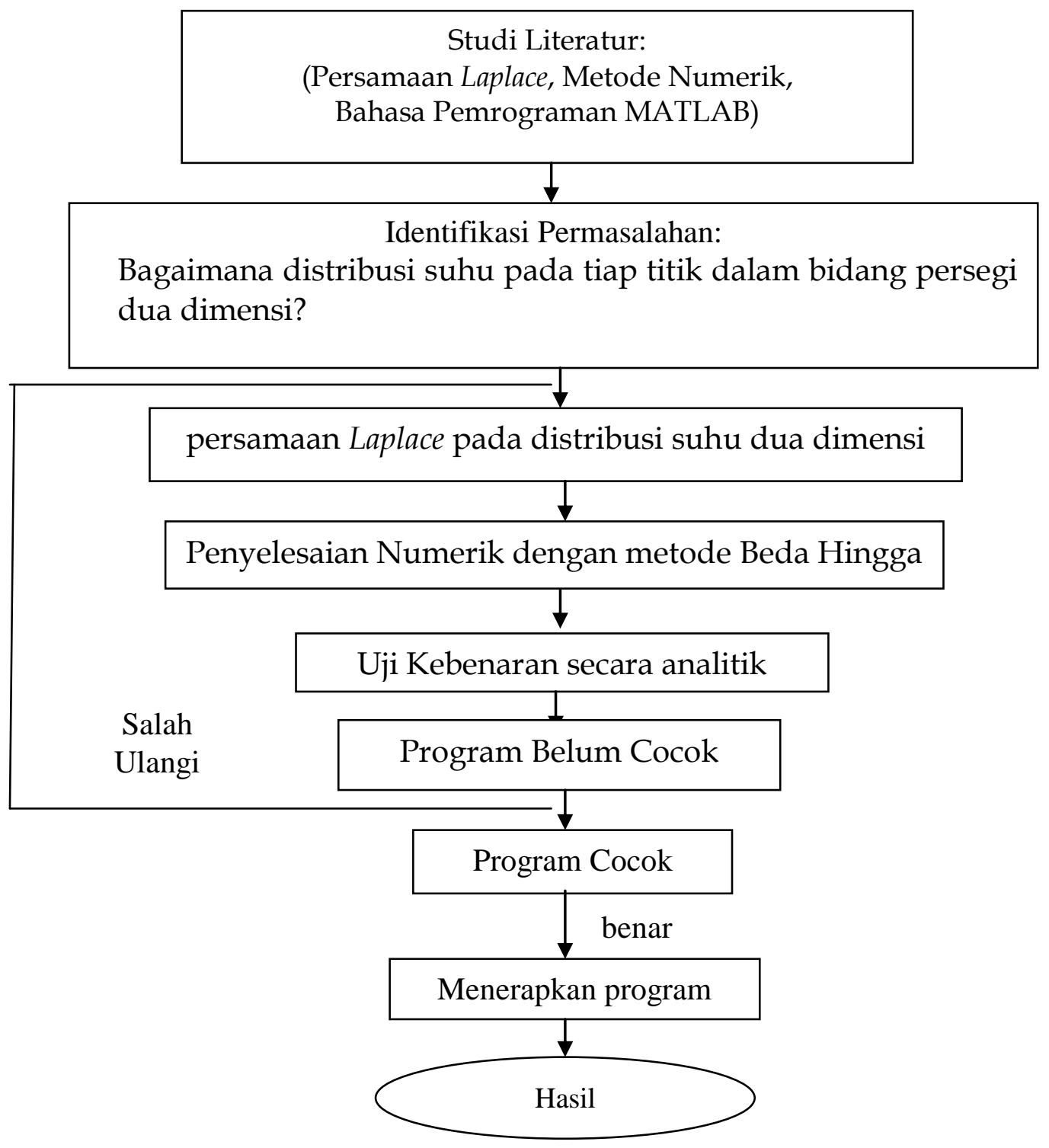

Gambar 1. Diagram alir penelitian

\section{HASIL DAN PEMBAHASAN}

Program komputer untuk persamaan Laplace pada peristiwa distribusi suhu berasal dari J. Alberty, C. Carstensen and S. A. Funken [6] dengan modifikasi bentuk tampilan yang mulanya segitiga tidak tertutup / bentuk topi diganti dengan bentuk persegi. Selain itu batasan pada sisi atau batasannya diganti menjadi $\mathrm{x}=0, \mathrm{y}=0$ dan $\mathrm{T}=1^{0}$ yang disesuaikan dengan distibusi suhu persamaan Laplace pada koordinat kartesian. Program ini menampilkan distribusi suhu persamaan Laplce dua dimensi dengan metode beda hingga dimana arah distribusi suhunya semakin meningkat. Pada program ini dibuat suhu berawal dari $\mathrm{T}=0$ hingga suhunya meningkat (panas) dengan $\mathrm{T}=$ 0,5 dengan nilai batas $\mathrm{x}$ dan $\mathrm{y}$ yang berbeda. Persamaan Laplace dua dimensi pada koordinat kartesian yang digunakan adalah:

$T(x, y)=\frac{100}{\pi} \sum_{n=1}^{\infty}\left(\frac{1}{n}\left(1-(-1)^{n}\right)\left(\sin \frac{n \pi x}{d}\right)^{\prime}\right.$

Berikut akan dibahas tentang beberapa hasil visualisasi dari program komputer yang telah diterapkan. 




Gambar 2. Distribusi Suhu Persamaan Laplace Dua Dimensi dengan Nilai $\mathrm{X}=0, \mathrm{Y}=0$, Dan $\mathrm{T}$ $=0$

Pada gambar 2 diatas nilai $\mathrm{x}=0$, $\mathrm{y}=0$ dan $\mathrm{T}$ dalam hal ini ditunjukkan oleh metode beda hingga dengan huruf $\mathrm{Z}$, dimana nilai $\mathrm{T}=0$. Angka yang didapatkan pada metode numerik dengan program MATLAB tidak jauh berbeda dengan perhitungan secara analitiknya. Pada metode analitik dengan nilai $\mathrm{x}=0, \mathrm{y}=0$ maka $\mathrm{T}$ juga bernilai 0 .

Pada gambar 3 dibawah nilai $\mathrm{x}=$ 0,1667, $\mathrm{y}=0,25$ dan $\mathrm{T}=0,1528$. Angka yang didapatkan pada metode numerik dengan program MATLAB tidak jauh berbeda dengan perhitungan secara analitiknya. Pada metode analitik dengan nilai $\mathrm{x}=0,1667, \mathrm{y}=0,25$ maka $\mathrm{T}$ juga bernilai 0,16 . Gambar 3 dibawah nilai $\mathrm{x}=0,5, \mathrm{y}=0,25$ dan $\mathrm{T}=0,3749$. Angka yang didapatkan pada metode numerik dengan program MATLAB tidak jauh berbeda dengan perhitungan secara analitiknya. Pada metode analitik dengan nilai $\mathrm{x}=0,5, \mathrm{y}=0,25$ maka $\mathrm{T}$ juga bernilai 0,3749 .

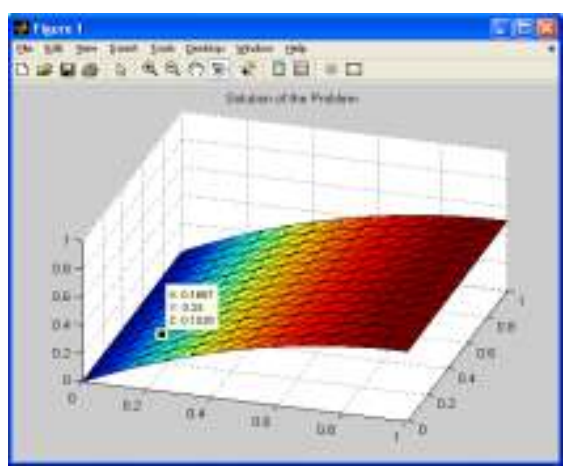

Gambar 3. Distribusi Suhu Persamaan Laplace dua dimensi dengan nilai $\mathrm{x}=0,1667, \mathrm{y}=0,25$ dan $\mathrm{T}=0,1528$

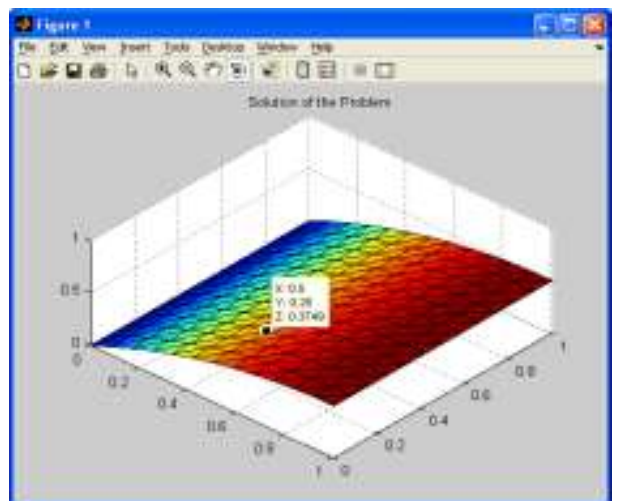

Gambar 4. Distribusi Suhu Persamaan Laplace dua dimensDengan nilai $\mathrm{x}=0,5, \mathrm{y}=0,25$ dan $\mathrm{T}$ $=0,3749$

Gambar 4 diatas nilai $\mathrm{x}=$ 0,5833, $\mathrm{y}=0,0833$ dan $\mathrm{T}=0,413$. Angka yang didapatkan pada metode numerik dengan program MATLAB tidak jauh berbeda dengan perhitungan secara analitiknya. Pada metode analitik dengan nilai $\mathrm{x}=0,5833, \quad \mathrm{y}=0,0833$ maka $\mathrm{T}$ juga bernilai 0,476 .

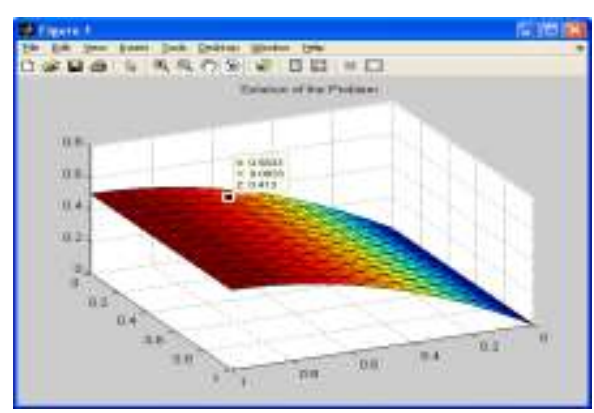

Gambar 5. Distribusi Suhu Persamaan Laplace dua dimensi Dengan nilai $\mathrm{x}=0,5833, \mathrm{y}=$ 0,0833 dan $\mathrm{T}=0,413$

Dari gambar 2 hingga gambar 5 menunjukkan distribusi suhu dari $\mathrm{T}=0$ hingga mengalami peningkatan. Dimana perubahan $\mathrm{T}$ dari setiap titik dipengaruhi oleh nilai $\mathrm{x}$ dan y yang dimasukkan berbeda. Pada setiap kejadian nilai $\mathrm{x}$ dan nilai $y$ antara perhitungan secara numerik dengan analitiknya dibuat sama. Hal ini dilakukan supaya mengetahui kecocokan atau kevalidan perhitungan berdasarkan numerik dan analitik. Peningkatan suhu pada grafik hasil program digambarkan dengan warna yang berbeda, dimana warna biru menunjukkan posisi suhu dalam keadaan $\mathrm{T}=0$ dengan $\mathrm{x}=0$ dan $\mathrm{y}=0$. Sedangkan warna hijau menunjukkan perubahan suhu dari $\mathrm{T}=0$ menuju $\mathrm{T}=$ 0,2188 dengan nilai $\mathrm{x}=0,25$ dan $\mathrm{y}=$ 
0,5833, warna kuning juga menunjukkan bahwa suhu tersebut meningkat menjadi $\mathrm{x}=0,6667, \mathrm{y}=$ 0,5833 dan $\mathrm{T}=0,4445$. Warna merah muda Sedangkan warna merah pekat menunjukkan suhu sudah berada pada tingkat yang tinggi dengan $\mathrm{x}=1, \mathrm{y}=$ 0,5 dan $\mathrm{T}=0,5$. Distribusi suhu persamaan Laplace dua dimensi dari hasil program syarat batas yang dimasukkan pada bidang $\mathrm{x}=0, \mathrm{y}=0$ dan $\mathrm{T}=1^{0}$.

Kemudian berdasarkan grafik hasil program yang dibuat apabila disesuaikan dengan teori maka grafik tersebut ada kecocokan. Grafik tersebut ditunjukkan seperti dibawah ini;


Gambar 6. Grafik aliran suhu pada teori [7]

Gambar diatas menjelaskan bahwa dalam teori konduksi panas, asumsi yang dibuat adalah panas yang mengalir ke arah penurunan suhu. Jika kita menganggap bahwa tidak ada energi panas yang dibuat, maka jumlah panas bersih mengalir melalui setiap kecil segi empat dengan panjang sisi $\Delta \mathrm{x}$ dan $\Delta \mathrm{Y}$ nol adalah sama (lihat Gambar 4.5 (a)). Hal ini mengarah kepada kesimpulan bahwa $\mathrm{T}(\mathrm{x}, \mathrm{y})$ adalah fungsi harmonis. Heuristis argumen berikut ini sering digunakan untuk menunjukkan bahwa $\mathrm{T}(\mathrm{x}, \mathrm{y})$ memenuhi Laplace's equation. Adapun bentuk grafiknya seperti gambar dibawah ini. Kurva $\mathrm{T}(\mathrm{x}, \mathrm{y})=\mathrm{K}_{1}$ dipanggil isothermals dan saluran yang menghubungkan poin yang sama suhu. Pada $s(x, y)=K_{z}$ disebut arus panas baris, dan satu dapat memvisualisasikan panas ini mengalir di sepanjang poin kurva dari suhu tinggi ke tempat yang lebih rendah suhu. Situasi ini diilustrasikan dalam gambar 5 (b) [7].

Jadi pada grafik atau gambar diatas menunjukan distribusi suhu dari rendah ke suhu yang tinggi secara teori (analitik), hal ini sesuai dengan grafik yang dihasilkan dari program. Dimana grafik pada program secara numerik juga menunjukkan arah meningkatnya suhu yang berawal dari suhu yang rendah. Grafik diatas maupun pada program bisa juga menunjukkan arah distribusi suhu dari tinggi menuju suhu yang rendah.

Berikut ini hasil perbandingan perhitungan antara metode numerik dengan metode analitik.

Tabel 1. Perhitungan secara analitik dan numerik pada persamaan Laplace

\begin{tabular}{|c|c|c|c|}
\hline \multirow{2}{*}{$\mathrm{x}$} & & \multicolumn{2}{|c|}{ Nilai T } \\
\cline { 3 - 4 } & $\mathrm{y}$ & Numerik & Analitik \\
\hline 0 & 0 & 0 & 0 \\
\hline 0,1667 & 0,25 & 0,1528 & 0,16 \\
\hline 0,125 & 0,25 & 0,2187 & 0,22 \\
\hline 0,5 & 0,25 & 0,3749 & 0,288 \\
\hline 0,5833 & 0,0833 & 0,413 & 0,476 \\
\hline
\end{tabular}

Berdasarkan tabel diatas menunjukkan antara perhitungan analitik dengan numerik tidak terjadi perbedaan yang terlalu signifikan. Pada saat nilai $\mathrm{x}=0$ dan $\mathrm{y}=0$ maka nilai $\mathrm{T}$ anatara analitik maupun numerik sama dengan 0 . Sedangkan Pada saat nilai $\mathrm{x}=0,1667$ dan $\mathrm{y}=0,25$ pada perhitungan secara analitik nilai $\mathrm{T}=0,16$, sedangkan pada penyelesaian secara numerik dengan nilai $x$ dan $y$ yang sama dengan analitiknya nilai $\mathrm{T}=0,1528$ didapatkan nilai error atau selisihnya hanya 0,0072 . Selanjutnya pada saat nilai $\mathrm{x}=0,5$ dan $\mathrm{y}$ $=0,25$ pada perhitungan secara analitik nilai $\mathrm{T}=0,288$, sedangkan pada penyelesaian secara numerik dengan nilai $x$ dan $y$ yang sama dengan analitiknya nilai $\mathrm{T}=0,3749$ didpatkan nilai error atau selisihnya hanya $0,0869$. Saat nilai $\mathrm{x}=0,5833$ dan $\mathrm{y}=0,0833$ pada perhitungan secara analitik nilai $\mathrm{T}$ $=0,476$, sedangkan pada penyelesaian secara numerik dengan nilai $\mathrm{x}$ dan $\mathrm{y}$ yang sama dengan analitiknya nilai $\mathrm{T}=$ 0,413 didpatkan nilai error atau selisihnya hanya 0,063 . 


\section{SIMPULAN DAN SARAN}

\subsection{Simpulan}

Hasil visualisasi berupa grafik pada program MATLAB untuk menyelesaikan persamaan Laplace telah ada kecocokan dengan grafik pada teori tentang distribusi suhu, sehingga antara hasil teori dan numerik berupa program tidak ada perbedaan yang signifikan. Bahkan hasilnya berdasarkan grafik diatas menunjukkan bahwa antara numerik dengan analitik saling berhimpit atau mendekati. Hal ini dapat dilihat dari selisih atau tingkat error nilai $\mathrm{T}$ antara numerik dengan analitik tidak terlalu jauh perbedaannya.

- Pada saat nilai $x=0$ dan $y=0$ maka nilai $\mathrm{T}$ anatara analitik maupun numerik sama dengan 0 . Sedangkan pada saat nilai $\mathrm{x}=$ 0,1667 dan $\mathrm{y}=0,25$ pada perhitungan secara analitik nilai $\mathrm{T}=0,16$, sedangkan pada penyelesaian secara numerik dengan nilai $\mathrm{x}$ dan y yang sama dengan analitiknya nilai $\mathrm{T}=$ 0,1528 didapatkan nilai error atau selisihnya hanya 0,0072 . Selanjutnya pada saat nilai $\mathrm{x}=$ 0,5 dan $\mathrm{y}=0,25$ pada perhitungan secara analitik nilai $\mathrm{T}=0,288$, sedangkan pada penyelesaian secara numerik dengan nilai $\mathrm{x}$ dan y yang sama dengan analitiknya nilai $\mathrm{T}=$ 0,3749 didapatkan nilai error atau selisihnya hanya 0,0869 . Saat nilai $\mathrm{x}=0,5833$ dan $\mathrm{y}=$ 0,0833 pada perhitungan secara analitik nilai $\mathrm{T}=0,476$, sedangkan pada penyelesaian secara numerik dengan nilai $x$ dan $y$ yang sama dengan analitiknya nilai $\mathrm{T}=0,413$ didapatkan nilai error atau selisihnya hanya 0,063 .

\subsection{Saran}

1. Untuk distribusi suhu pada persamaan Laplace perlu dilakukan penelitian lebih lanjut dengan syarat batas yang berbeda misalkan $\mathrm{x}=1, \mathrm{y}=2$, dan $\mathrm{T}=100^{\circ}$

2. Program hasil penelitian distribusi suhu pada persamaan ini perlu dilakukan penelitian lebih lanjut pada bidang tiga dimensi supaya lebih menemukan hasil yang jauh lebih baik dan akurat

\section{DAFTAR PUSTAKA}

[1] Boas, M. L., 1983.Mathematical Methods In The Physical Sciences. Singapura: John Wiley \& Sons

[2] Wospakrik J.H., 1998.Dasar-Dasar Matematika Untuk Fisika. Jakarta: Departemen Pendidikan dan Kebudayaan Direktorat Jenderal Pendidikan Tinggi

[3] Huebner, K.H., 2001. The Finite Element Method for Engineers. Singapura: John Wiley \& Sons,

[4] Fagan , M. J., 1992. Finite Element Analysis, Theory and Practice, Longman Scientific and Technical, Essex, England.

[5] http://www.scs.fsu.edu/ burkardt/pdf/ac f.pdf, (diakses 10 Juli 2008)

[6] http://www.math.tuwien.ac.at/ carsten/s oftware.htm, (diakses 12 Desember 2007)

[7]

http://math.fullerton.edu/mathews/c2 003/TemperaturesMod.html, (diakses 27Juli 2008) 